\title{
Two New Species of Dipogon (Deuteragenia) (Insecta: Hy- menoptera: Pompilidae) from Subtropical Islands of Japan
}

\author{
Akira Shimizu \\ Department of Biological Sciences, Graduate School of Science and Engineering, \\ Tokyo Metropolitan University, Minami-Ohsawa 1-1, Hachioji, Tokyo, 192-0397 Japan \\ E-mail: shimizu-akira@c.metro-u.ac.jp
}

(Received 9 May 2006; Accepted 30 August 2006)

\begin{abstract}
Two new species of the pompilid wasp genus Dipogon occurring in the subtropical islands of Japan are described: Dipogon (Deuteragenia) amamiensis from Amami-Ohshima in the northern Ryukyu Islands, and Dipogon (Deuteragenia) ogasawarensis from Haha-jima in the Ogasawara Islands (Bonin Islands). A brief discussion of the distribution of the Japanese species of Dipogon (Deuteragenia) is provided.
\end{abstract}

Key Words: systematics, Hymenoptera, Pompilidae, Pepsinae, Dipogon (Deuteragenia), new species, Japan.

\section{Introduction}

The spider-wasp genus Dipogon Fox, 1897 is one of the most distinctive genera of the pompilid subfamily Pepsinae. Members of this genus have several unique morphological features, such as a fascicle of very long, curved bristles on the maxillary cardo and an upwardly curved sting in the female (Shimizu and Ishikawa 2002a). These wasps utilize pre-existing holes in wood, hollow stems, walls, and other cavities for their nest cells, which are closed with various compacted materials.

Deuteragenia Sustera, 1912 is the largest among the subgenera of Dipogon and its species have the most generalized habitus in the genus. They are widely distributed throughout the world except in the Australian region. Seven species are known to occur in Western Europe (Wahis 1986, 2005), and 14 species in North and Central America (Townes 1957; Evans 1974; Krombein 1979; Poole 1996). Shimizu and Ishikawa (2002a, 2002b, 2003) revised the Japanese species of Deuteragenia. They treated 11 species, five of which were new, and tentatively divided them into five species-groups, i.e., the groups of Dipogon (Deuteragenia) conspersus (Pérez, 1905), D. (D.) vechti Day, 1979, D. (D.) granulifrons Shimizu and Ishikawa, 2002, $D$. (D.) immarginatus (Gussakovskij, 1933), and D. (D.) bifasciatus (Geoffroy, 1785).

In my recent examination of material deposited in the Department of Zoology, National Science Museum, Tokyo, and the Laboratory of Systematic Zoology, Tokyo Metropolitan University, Tokyo, I discovered two females referable to two separate and undescribed species of the subgenus Deuteragenia. One species is from the island of Amami-Ohshima in the northern Ryukyu Islands, and the other species is from Haha-jima, one of the Ogasawara Islands (Bonin Islands). This paper provides formal descriptions of these two new species and a summary of the 
distribution of the Japanese species of Deuteragenia.

\section{Materials and Methods}

The terminology of the wing veins and cells follows Day (1988). The following morphological terms and abbreviations are used in the descriptions: antennocular line, anterior margin of frons in dorsal view; maxillary beard, a fascicle of long, stout, curved setae on the maxillary cardo; LID, lower interocular distance; MID, middle interocular distance; OOL, ocello-ocular line; POL, postocellar line; SMC, submarginal cell of forewing; UID, upper interocular distance. Specimen depositories are abbreviated as follows: NSMT, Department of Zoology, National Science Museum, Tokyo; TMUZ, Laboratory of Systematic Zoology, Department of Biological Sciences, Tokyo Metropolitan University, Tokyo.

\section{Systematics}

Dipogon (Deuteragenia) amamiensis sp. nov. [Japanese name: Amami-hige-kumobachi]

(Figs 1-13)

Type material. Holotype: $q$, Shinmura, Sumiyo Village, Amami-Ohshima Island, northern Ryukyu Islands, 28 August 1958, S. Uéno leg., TMUZ-2006-001.

Diagnosis. This species is distinguished from other species of the subgenus Deuteragenia occurring in Japan and adjacent regions by the following characteristics: head and mesosoma matte; apical rim of clypeus scarcely depressed but set off from main part of clypeus by absence of both punctures and pubescence (Fig. 12); apical margin of clypeus almost straight without median emargination; flagellomere I very slender (Fig. 5), much longer than UID; vertex and upper frons with several erect setae, these being less than $0.5 \times$ as long as longest seta by inner orbit on each side of vertex (Fig. 2); frons above antennal sockets with fine and dense punctures, spaces between punctures being narrower than diameter of each puncture (Fig. 11); POL slightly greater than OOL; propodeum long and gently convex in profile (Fig. 8), minutely and reticulately rugulose with strong transverse rugae posterolaterally (Fig. 13) and several suberect white setae, these being much shorter than those on metasomal tergum VI; metasomal tergum I distinctly petiolate (Fig. 6); sternum II with sharply impressed line immediately behind transverse groove (Fig. 7); and forewing with ill-defined, subapical white area (Fig. 9).

Description. Holotype female. Body length $7.9 \mathrm{~mm}$; forewing length $6.8 \mathrm{~mm}$.

Body black. Following areas ferruginous: pronotum laterally, metasomal terga laterally and posteriorly, metasomal sterna anteriorly and posteriorly, and apical half of mandible. Antenna and legs brownish black, possibly caused by secondary discoloration; palpi brown; maxillary beard dark brown. Tarsal claws yellowish brown. Wing hyaline; forewing broadly and distinctly bifasciate, feebly and narrowly infuscate apically (Fig. 9); hindwing feebly but broadly infuscate apically.

Head and mesosoma finely and densely punctate, except for disc of metanotum, metapleuron, and propodeum, these areas being minutely reticulate-rugulose (propodeum without median smooth area); metanotum laterally exhibiting several 


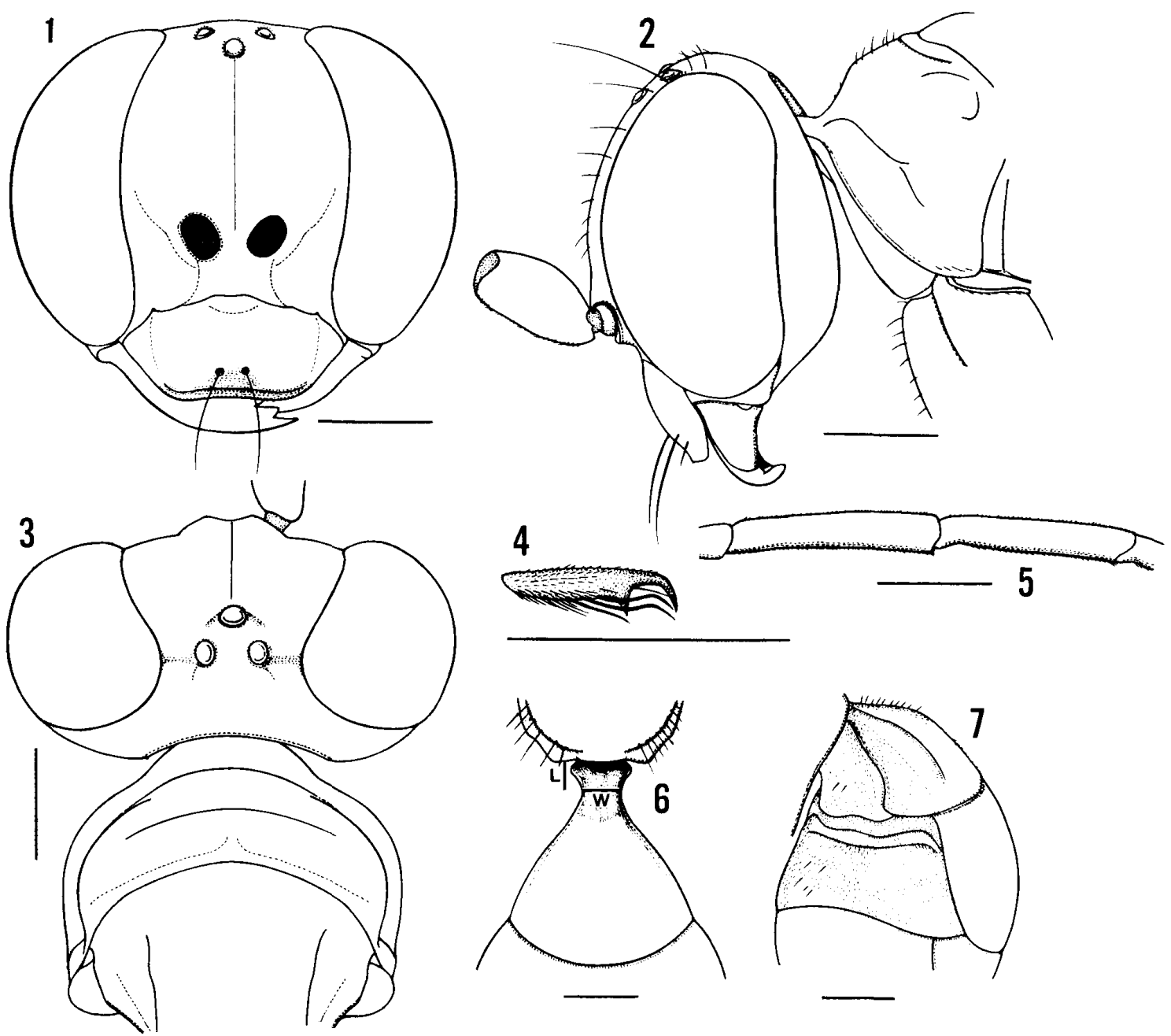

Figs 1-7. Dipogon (Deuteragenia) amamiensis sp. nov., holotype female. 1, Head, frontal view; 2,3 , head and pronotum, lateral (2) and dorsal (3) views; 4, left mesotarsal claw, outer view; 5 , right flagellomere I and II, dorsal view; 6, metasomal tergum I, dorsal view (L, length of petiole between base and greatest constriction; W, minimum width of petiole); 7 , metasomal terga I and II, ventrolateral view. Scales: $0.5 \mathrm{~mm}$.

strong striae; metapostnotum with few transverse striae. Metasoma weakly polished with very fine, dense punctures.

Body with very short, decumbent, white pubescence conferring a pruinose appearance. Body not setose; propodeum posterolaterally, propleuron, and procoxa with moderately long, white setae; metasomal terga V-VI and sterna IV-VI with long, stiff, dark brown setae; setae on remainder of body and legs very short and sparse.

Head in frontal view $1.2 \times$ as wide as long (Fig. 1). Vertex feebly convex between eye tops. Supra-antennal area of frons slightly raised above level of clypeus in lateral view (Fig. 2); median line barely impressed from supra-antennal area to anterior ocellus. Antennocular line weakly inclined from antennal base toward eye (Fig. 3). Inner orbits arcuate, much more strongly convergent above than 

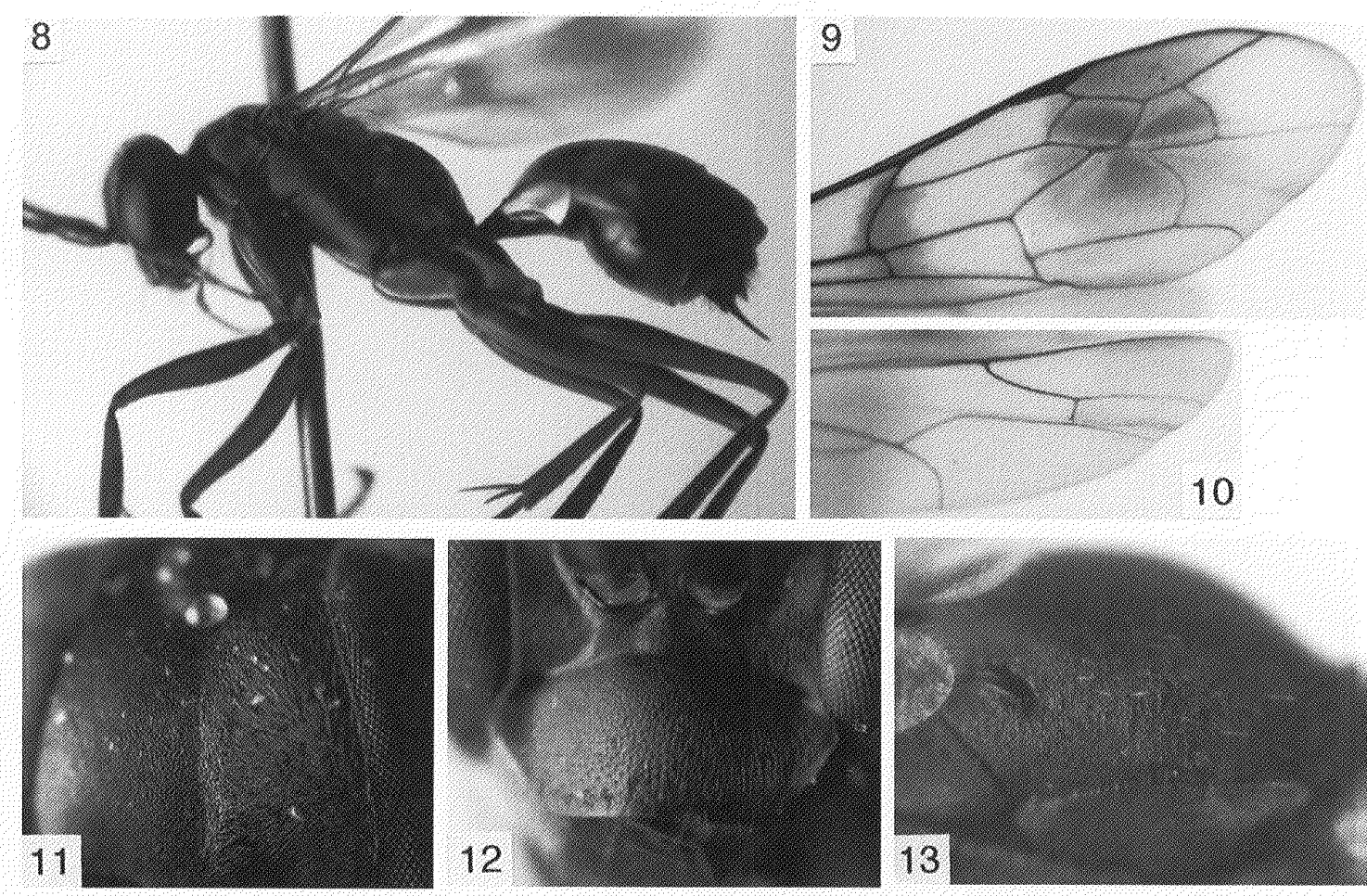

Figs 8-13. Dipogon (Deuteragenia) amamiensis sp. nov, holotype female. 8, Body and legs, lateral view, 9 , forewing, 10 , hind wing, 11, upper frons, frontal view; 12, clypeus, frontal view; 13 , propodeum, lateral view.

below; UID:MID :LID $=6.0: 10: 8.8$. MID $0.51 \times$ head width. Ocelli forming approximately equilateral triangle; ocellar area weakly raised. Eye in frontal view broadest slightly below middle. POL:OOL $=1: 0.85$. Clypeus much wider than LID (Fig. 1), $2.1 \times$ as wide as long, gently convex transversely and lengthwise except for lateral flattened area, without preapical ridge (Fig. 12); preapical setiferous pores strong; apical rim impunctate and alutaceous. Malar space very short and linear. Genae in dorsal view strongly receding and thin (Fig. 3 ), in profile $0.3 \times$ eye width (Fig. 2). Flagellomere I $5.5 \times$ as long as wide, $1.5 \times$ UID; flagellomeres I and II in length ratio of $10: 8.6$.

Pronotum in dorsal view comparatively long with lateral margins convergent posteriorly, so shoulder slightly swollen (Fig. 3); dorsum gently sloped (Fig. 2); posterior portion feebly depressed; posterior margin arcuate. Mesoscutum with posterolateral margin distinctly reflexed. Scutellum with disc convex, slightly raised above level of mesoscutum, distinctly narrowed posteriorly. Metapostnotum strongly declivous medially, triangularly emarginate posteriorly, $0.2 \times$ as long as metanotum at midline. Propodeum $1.2 \times$ as long as broad with stigmal furrow both anterior and posterior to spiracle; lateral margins gently convergent posteriorly; median groove vestigial.

Metasomal tergum I with part of petiole anterior to constriction shorter than wide (Fig. 6). Transverse groove on sternum II slightly incurved medially (Fig. 7).

Fore- and hindwings as shown in Figs 9 and 10, respectively. SMC2 rhomboid, receiving crossvein $1 \mathrm{~m}$-cu at basal 0.63 . SMC3 $1.3 \times$ as long as SMC2 on vein $M$, nar- 
rowed on vein Rs by $0.42 \times$ its length on vein $M$, receiving crossvein $2 \mathrm{~m}$-cu at basal 0.26 . Hindwing crossvein rs-m scarcely curved, nearly perpendicular to vein $M$ (Fig. 10). Jugal lobe $0.34 \times$ as long as subbasal (submedian) cell.

Profemur almost as thick as mesofemur. Mesotibia with several short spines dorsally and exteriorly. Metatibia less spinose than mesotibia, with minute spine dorsally and several ones exteriorly; apical outer margin with six short spines. Longer spur of metatibia $0.49 \times$ as long as tarsomere I. Tarsal claws each with stout, vertical tooth (Fig. 4).

Etymology. Named after the type locality, Amami-Oshima Island.

Dipogon (Deuteragenia) ogasawarensis sp. nov.

[Japanese name: Ogasawara-hige-kumobachi]

(Figs 14-25)

Type material. Holotype: $\&$, Mt. Chibusa, Haha-jima Island, Ogasawara Islands, 21 June 1976, S. Shinonaga leg., NSMT-I-Hym 26441.

Diagnosis. This species is distinguished from other species of the subgenus Deuteragenia occurring in Japan and adjacent regions by the following characteristics: body polished; apical rim of clypeus barely depressed, impunctate and alutaceous; apical margin of clypeus almost straight without median emargination (Fig. 24); flagellomere I not elongate (Fig. 18), much shorter than UID; vertex and upper frons with several erect setae, some being more than $0.5 \times$ as long as longest seta by inner orbit on each side of vertex (Fig. 15); frons above antennal sockets with fine, dense punctures, spaces between punctures on upper frons being usually broader than diameter of each puncture (Fig. 23); POL greater than OOL; propodeum short and spherically convex in profile (Fig. 20), propodeum except median portion finely and densely punctate, and transversely rugulose posterolaterally (Fig. 25) with several suberect white setae, these being much shorter than those on metasomal tergum VI; metasomal tergum I distinctly petiolate (Fig. 19); sternum II with sharply impressed line immediately behind transverse groove as in $D$. (D.) amamiensis (Fig. 7); forewing narrowly and obscurely bifasciate, without subapical white area (Fig. 21).

Description. Holotype female. Body length $6.6 \mathrm{~mm}$; forewing length $6.0 \mathrm{~mm}$.

Body and legs black; apical third of mandible, side of metasomal tergum I, and apices of tarsomeres ferruginous; palpi brown; maxillary beard golden; apical half of tarsal claws yellowish brown. Wings yellowish brown and transparent. Hindwing not infuscate apically.

Head and mesosoma moderately polished, metasoma more strongly polished. Head, mesoscutum, mesopleuron, and lower metapleuron finely and densely punctate; scutellum and disc of metanotum more weakly and sparsely punctate than head; metanotum with several strong striae laterally; metapostnotum with few fine striae anteriorly; upper metapleuron with fine, oblique striae and small punctures between them. Propodeum with irregularly-spaced, dense punctures, these weaker and sparser anteriorly; median area narrowly impunctate and shining. Metasoma with minute, dense punctures, these weaker and sparser on tergum I than on tergum II.

Body and legs with short, pale brown to white pubescence longer on lower 


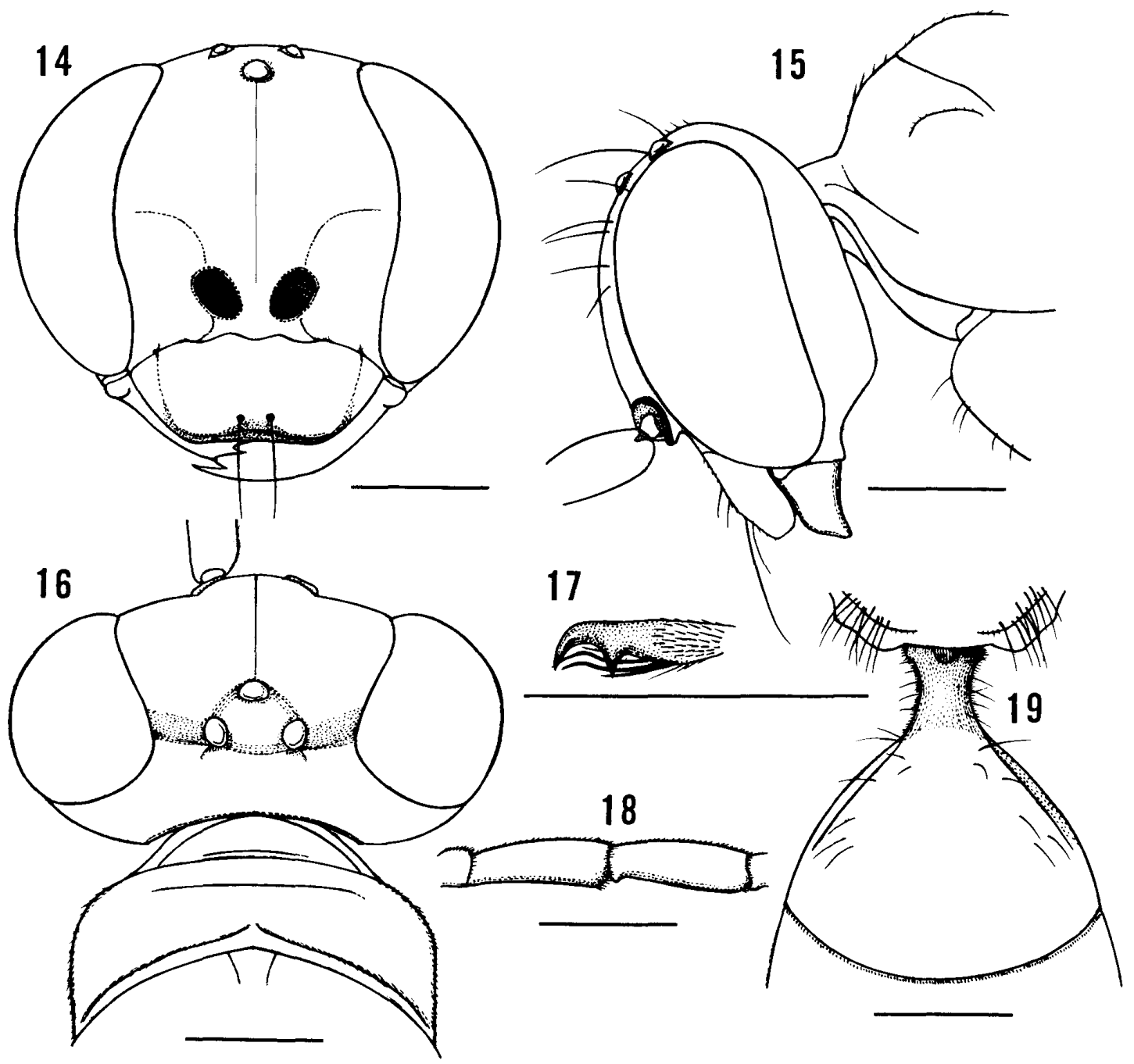

Figs 14-19. Dipogon (Deuteragenia) ogasawarensis sp. nov., holotype female. 14, Head, frontal view; 15, 16, head and pronotum, lateral (15) and dorsal (16) views; 17, right metatarsal claw, outer view; 18, right flagellomere I and II, dorsal view; 19, metasomal tergum I, dorsal view. Scales: $0.5 \mathrm{~mm}$.

frons, clypeus, basal half of mandible, lower gena, propleuron, lower mesopleuron, posterolateral portion of propodeum, and coxae. Gena and posterolateral portion of propodeum densely set with long, erect, white setae; propleuron, procoxa, and metasomal tergum I with comparatively dense, white setae laterally, shorter than those on gena and propodeum. Femora with very short, sparse, white setae. Metasomal terga IV-VI, posterior half of metasomal sternum II, and following sterna with long, stiff, white to brown setae becoming denser apicad.

Head in frontal view $1.2 \times$ as wide as long (Fig. 14). Vertex gently convex between eye tops. Supra-antennal area of frons moderately raised above level of clypeus in lateral view (Fig. 15); median line very fine from supra-antennal area to anterior ocellus. Antennocular line distinctly inclined from antennal base toward eye (Fig. 16). Inner orbits arcuate, more strongly convergent above than below; 


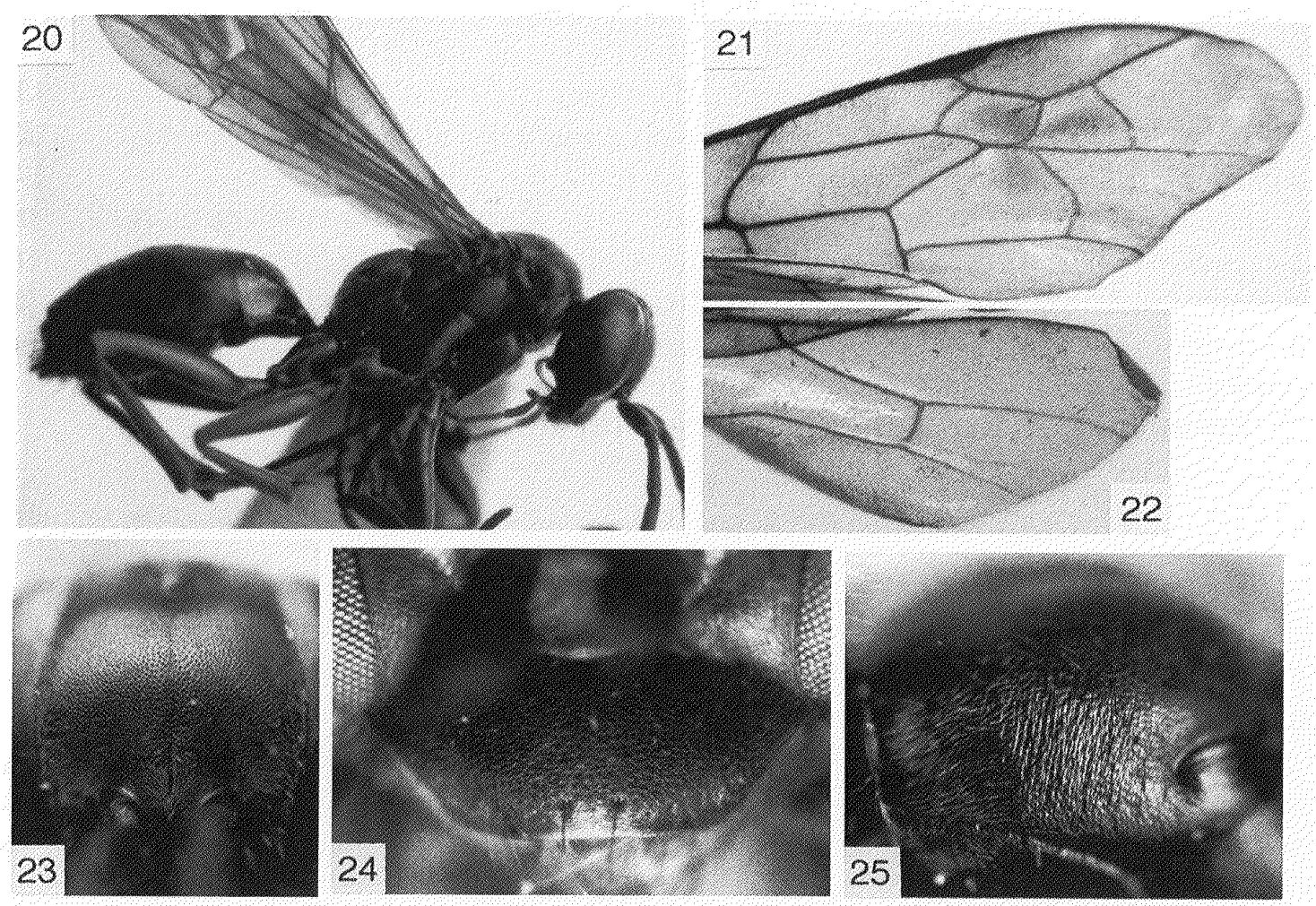

Figs 20-25. Dipogon (Deuteragenia) ogasawarensis sp. nov., holotype female. 20, Body and legs, lateral view; 21 , forewing, 22 , hind wing, 23 , upper frons, frontal view; 24 , clypeus, frontal view, 25 , propodeum, lateral view.

UID : MID : LID $=6.5: 10: 8.5$. MID $0.57 \times$ head width. Ocelli forming acute-angled triangle broader than equilateral one; ocellar area moderately raised. Eye in frontal view broadest at middle. POL:OOL $=1: 0.77$. Clypeus slightly wider than LID (Fig. 14), $2.2 \times$ as wide as long, gently convex transversely and lengthwise except for lateral flattened area, without preapical ridge (Fig. 24); preapical pores strong. Malar space very short and linear. Gena in dorsal view more gently receding and thicker than in D. (D.) amamiensis (compare Fig. 16 and Fig. 3), in profile $0.4 \times$ eye width (Fig, 15). Flagellomere $I 3.3 \times$ as long as wide, $0.79 \times$ UID, nearly as long as flagellomere II.

Pronotum in dorsal view comparatively short with lateral margins subparallel posteriorly, so shoulder scarcely swollen (Fig. 16); dorsum short and steeply sloped, declivity nearly perpendicular (Fig. 15); posterior portion feebly depressed; posterior margin subangulate medially. Mesoscutum with posterolateral margin narrowly reflexed. Scutellum with disc scarcely convex, barely raised above level of mesoscutum, gently narrowed posteriorly. Metapostnotum deeply sunken medially between metanotum and propodeum, arcuately emarginate posteriorly, less than $0.1 \times$ as long as metanotum along midline. Propodeum $0.94 \times$ as long as broad, with stigmal furrow only anterior to spiracle; lateral margins strongly convergent posteriorly; median groove very shallowly impressed.

Metasomal tergum I with part of petiole anterior to constriction shorter than wide (Fig. 19). Transverse groove on sternum II almost straight. 
Fore- and hindwing as shown in Figs 21 and 22, respectively. SMC2 receiving crossvein 1m-cu at basal 0.59. SMC3 $1.3 \times$ as long as SMC2 on vein M, narrowed on vein Rs by $0.47 \times$ its length on vein $M$, receiving crossvein $2 \mathrm{~m}$-cu at basal 0.10 . Hindwing crossvein rs-m slightly curved, somewhat oblique to vein M (Fig. 22). Jugal lobe $0.36 \times$ as long as subbasal cell.

Profemur slightly thicker than mesofemur. Mesotibia with several short, stout spines dorsally and exteriorly. Metatibia with 2 or 3 minute spines exteriorly and several short, suberect, white setae dorsally; apical outer margin with 3 (right tibia) or 4 (left tibia) short spines. Longer spur of metatibia $0.55 \times$ as long as tarsomere I. Tarsal claws each with stout, vertical tooth (Fig. 17).

Etymology. Named after the type locality, the Ogasawara Islands.

\section{Discussion}

The two new species described in this study are morphologically similar to $D$. (D.) immarginatus occurring in the Far East, but they are easily distinguished by the characters shown in Table 1.

Because our knowledge of the pompilid fauna of Korea and China is still fragmentary, any discussion of East Asian biogeography of Dipogon must be considered preliminary; nevertheless, I would like to take this opportunity to provide some remarks on the distribution of the subgenus Deuteragenia.

Distributional records on the Japanese species are summarized in Table 2. Their distributional patterns fall into three categories as follows:

(1) Palaearctic (from Europe through Central Asia and the Russian Far East to Japan): D. (D.) vechti and D. (D.) bifasciatus.

Table 1. Comparison of differential characters among three similar species of Dipogon (Deuteragenia).
D. (D.) amamiensis sp. nov.
D. (D.) ogasawarensis sp. nov.
D. (D.) immarginatus

1. Anterior margin of clypeus without median emargination

2. Clypeus much wider than LID

3. Flagellomere I more than $5 \times$ as long as wide, much longer than UID

4. POL $>$ OOL

5. Propodeum minutely and reticulately rugulose with transverse rugae posterolaterally

6. Forewing hyaline with well defined dark fascia
Anterior margin of clypeus without median emargination

Clypeus slightly wider than LID

Flagellomere I less than $4 \times$ as long as wide, much shorter than UID

POL $>$ OOL

Propodeum finely punctate with transverse rugae posterolaterally

Forewing transparent, yellowish brown, fasciae not well defined
Anterior margin of clypeus with median emargination

Clypeus much wider than LID

Flagellomere I less than $4 \times$ as long as wide, much shorter than UID

POL $\leqq$ OOL

Propodeum finely and densely punctate without transverse rugae

Forewing hyaline with well defined dark fasciae

Abbreviations: LID, lower interocular distance; OOL, ocello-ocular line; POL, postocellar line; UID, upper interocular distance. 
Two new species of Dipogon from Japan

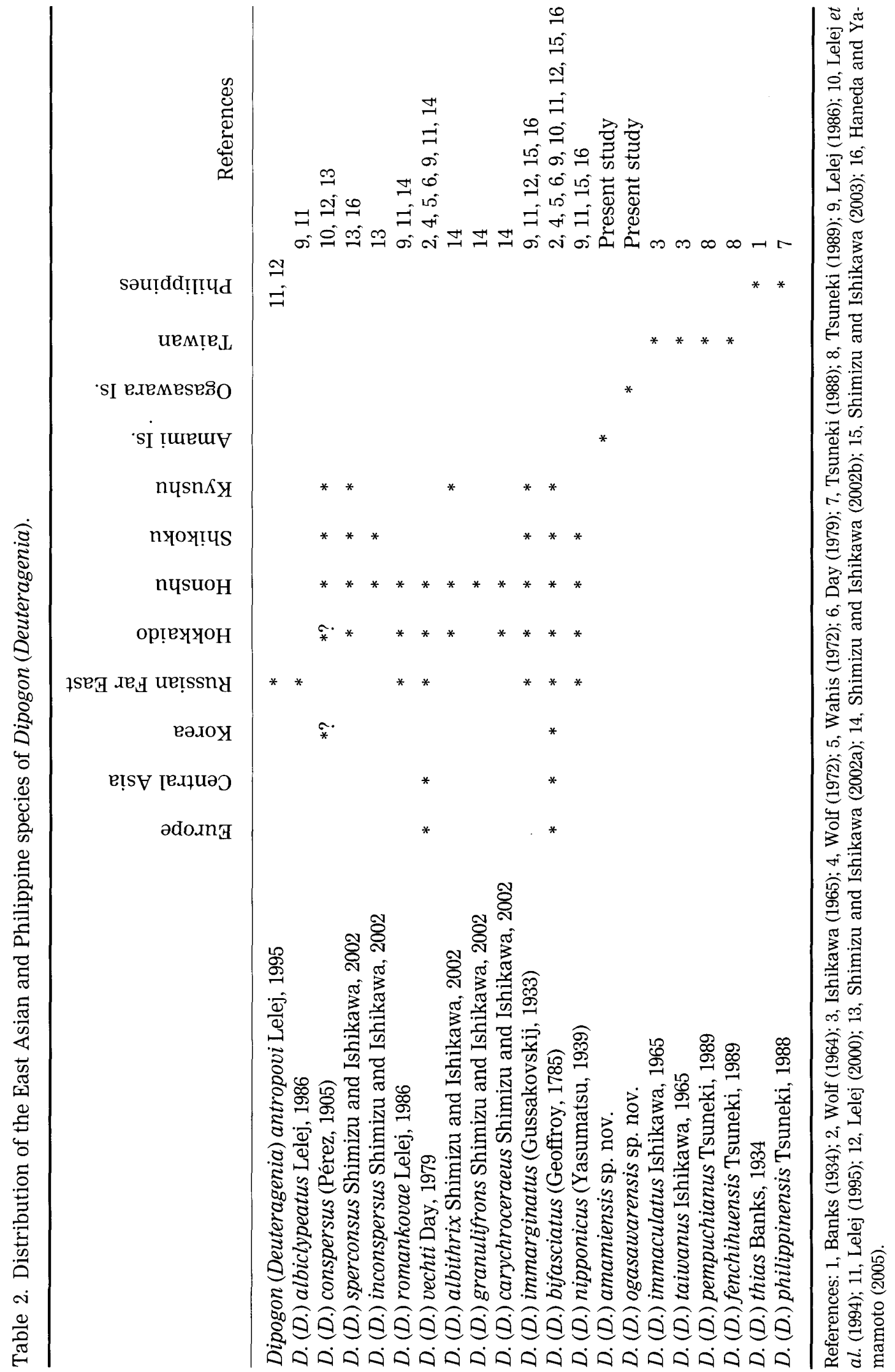


In D. (D.) bifasciatus, specimens from the Far East (Russian Far East and Japan) and those from Europe differ in the structure of the male antenna (Shimizu and Ishikawa 2003, figs 42-44): flagellomeres III-XI are serrate below in the former, but either are not, or are but scarcely serrate, in the latter (see also Wolf 1964 and Wahis 1972, as D. (D.) hircanum (Fabricius, 1798)). However, these specimens are hardly distinguishable in other characters, including the structure of the male genitalia and subgenital plate.

(2) Far Eastern (Russian Far East and the Japanese Archipelago): D. (D.) romankovae Lelej, 1986, D. (D.) immarginatus, and D. (D.) nipponicus (Yasumatsu, 1939).

(3) Indigenous to the Japanese Archipelago: $D$. (D.) conspersus, $D$. (D.) sperconsus Shimizu and Ishikawa, 2002, D. (D.) inconspersus Shimizu and Ishikawa, 2002, $D$. (D.) albithrix Shimizu and Ishikawa, 2002, D. (D.) granulifrons, and D. (D.) carychroceraeus Shimizu and Ishikawa, 2002.

Lelej et al. (1994) recorded D. (D.) conspersus from Korea and Hokkaido; these records need to be confirmed, however, because $D$. $(D$.) conspersus is very similar to $D$. (D.) sperconsus and was not recognized as a distinct species prior to 2002 . The latter species has been recorded in Hokkaido, Honshu, and Kyushu (Shimizu and Ishikawa 2002a). Although I examined 82 specimens of $D$. (D.) conspersus deposited at TMUZ, there were none from Hokkaido. I also examined 62 specimens of Deuteragenia that Mr K. Sayama collected in a suburb of Sapporo, Hokkaido, using trap nests. This series consisted of $D$. (D.) sperconsus, $D$. (D.) romankovae, $D$. (D.) al bithrix, and $D$. (D.) bifasciatus but did not include individuals of $D$. (D.) conspersus. Consequently, it is possible that $D$. (D.) sperconsus rather than $D$. (D.) conspersus is distributed in Korea, as well as in Hokkaido.

Dipogon (Deuteragenia) amamiensis and $D$. (D.) ogasawarensis may be endemic to the Amami and Ogasawara Islands, respectively. Neither species matches the definition of any of the species-group presented by Shimizu and Ishikawa (2002a, $2002 \mathrm{~b}, 2003)$. For recognition of the species-group, male morphological characters, especially structures of the subgenital plate and lateral hook of the metasomal sternum VI, are very important. Because male specimens have not been available for study for the two new species, it is difficult to discuss satisfactorily their taxonomic position. Based on female adult morphology, there is no evidence that they are closely related to each other. It is unclear whether or not they belong to the same species-group.

\section{Acknowledgments}

I thank Emeritus Professor R. Ishikawa (Tokyo Metropolitan University), Dr M. S. Wasbauer, and Mr H. Takahashi for reviewing the manuscript and providing critical comments. For the gift or loan of specimens, I thank the following persons: R. Ishikawa, H. Nagase, A. S. Lelej, K. Sayama, A. Shinohara, S. Shinonaga, and S. Uéno. 


\section{References}

Banks, N. 1934. The Psammocharidae of the Philippines. Proceedings of the American Academy of Arts and Sciences 69: 1-117.

Day, M. C. 1979. Nomenclatural studies on the British Pompilidae (Hymenoptera). Bulletin of the British Museum (Natural History), Entomological Series 38: 1-26.

Day, M. C. 1988. Spider wasps. Hymenoptera: Pompilidae. Handbooks for the Identification of British Insects 6: 1-60.

Evans, H. E. 1974. A review of the species of Dipogon occurring in Central America, Mexico, and extreme southwestern United States (Hymenoptera, Pompilidae). Transactions of the American Entomological Society 100: 29-51.

Haneda, Y. and Yamamoto, E. 2005. [Aculeate wasps in and around Odamiyama (Supplement 2)]. Shikoku-kogera 3: 45-66. [In Japanese]

Ishikawa, R. 1965. Studies on some Taiwan Pompilidae (Hymenoptera). Kontyû 33: 507-520.

Krombein, K. V. 1979. Family Pompilidae. Pp. 1523-1570. In: Krombein, K. V., Hurd, P. D., Smith, D. R. and Burks, B. D. (Eds) Catalog of Hymenoptera in America North of Mexico. Smithsonian Institution Press, Washington, D. C.

Lelej, A. S. 1986. Spider wasps of genera Dipogon Fox and Poecilageniella Ishikawa (Hymenoptera, Pompilidae) of the Far East. Revue d'Entomologie de l'URSS 65: 799-808. [In Russian]

Lelej, A. S. 1995. [Superfam. Pompiloidea]. Pp. 211-264. In: Lehr, P. A. (Ed.) Key to the Insects of Russian Far East in Six Volumes. Vol. 4. Neuropteroidea, Mecoptera, Hymenoptera. Part 1. Nauka, St. Petersburg. [In Russian]

Lelej, A. S. 2000. [Superfam. Pompiloidea]. Pp. 615-624. In: Lehr, P. A. (Ed.) Key to the Insects of Russian Far East in Six Volumes. Vol. 4. Neuropteroidea, Mecoptera, Hymenoptera. Part 4. Dal'nauka, Vladivostok. [In Russian]

Lelej, A. S., Saigusa, T. and Lee, C. E. 1994. Spider wasps (Hymenoptera, Pompilidae) of Korea. Russian Entomological Journal 3: 135-148.

Poole, R. W. 1996. Nomina Insecta Nearctica. A Check List of the Insects of North America. Volume 2: Hymenoptera, Mecoptera, Megaloptera, Neuroptera, Raphidioptera, Trichoptera. Entomological Information Services, Rockville, Maryland, U.S.A., 793 pp.

Shimizu, A. and Ishikawa, R. 2002a. Taxonomic studies on the Pompilidae occurring in Japan north of the Ryukyus: genus Dipogon, subgenus Deuteragenia (Hymenoptera) (Part 1). Entomological Science 5: 219-235.

Shimizu, A. and Ishikawa, R. 2002b. Taxonomic studies on the Pompilidae occurring in Japan north of the Ryukyus: genus Dipogon, subgenus Deuteragenia (Hymenoptera) (Part 2). Entomological Science 5: 361-373.

Shimizu, A. and Ishikawa, R. 2003. Taxonomic studies on the Pompilidae occurring in Japan north of the Ryukyus: genus Dipogon, subgenus Deuteragenia (Hymenoptera) (Part 3). Entomological Science 6: 165-181.

Townes, H. 1957. Nearctic wasps of the subfamilies Pepsinae and Ceropalinae. Bulletin of the United States National Museum 209: 1-286, pls 1-4.

Tsuneki, K. 1988. Pompilidae recently collected in the Philippines (Hymenoptera). Special Publications of the Japan Hymenopterists Association 34: 1-55, 61-62.

Tsuneki, K. 1989. A study of the Pompilidae of Taiwan (Hymenoptera). Special Publications of the Japan Hymenopterists Association 35: 1-180.

Wahis, R. 1972. Données pour un Atlas des Hyménoptères de I'Europe occidentale Pompilides du genre Dipogon Fox 1887, sous-genre Deuteragenia Sustera 1912 (Pompilidae, Pepsinae). 
Bulletin des Recherches Agronomiques de Gembloux 7: 333-349.

Wahis, R. 1986. Catalogue systématique et codage des Hyménoptères Pompilides de la region Ouest-Européenne. Notes Fauniques de Gembloux 12: 1-91.

Wahis, R. 2005. Sur quelques Pompilides nouveaux ou rares en France avec description d'un Dipogon nouveau: Dipogon fonfriai sp. n. et présence du genre Telostegus Costa (Hymenoptera: Pompilidae). Notes Fauniques de Gembloux 58: 37-56.

Wolf, H. 1964. Die nord- und mitteleuropäischen Arten der Gattung Dipogon Fox 1897, Untergattung Deuteragenia Šstera 1912 und der Gattung Pompilus Fabricius 1798, Untergattung Arachnospila Kincaid 1900 (Hym. Pompilidae). Opuscula Entomologica 29: 4-30.

Wolf, H. 1972. Insecta Helvetica. Fauna 5. Hymenoptera Pompilidae. Fotorotar, Zürich, 176 pp. 